\title{
Primary Cyst Hydatid in the Neck; Report of One Case
}

\author{
Boyunda Primer Kist Hidatik; Bir Olgu Sunumu
}

\author{
Uğur Kesici ${ }^{1}$, Sevgi Kesici², Ülkü Aygen Türkmen³, Hülya Ulusoy, Aslıhan Duman, \\ Gülen Burakgazi ${ }^{6}$, Erkan Yavuz $^{7}$
}

'Department of Surgery, Akçaabat Haçkalı Baba State Hospital, Trabzon, Turkey

2Department of Anesthesiology and Reanimation, Numune Training and Research Hospital, Trabzon, Turkey

${ }^{3}$ Department of Anesthesiology and Reanimation, Okmeydanı Training and Research Hospital, İstanbul, Turkey

${ }^{4}$ Department of Anesthesiology and Reanimation, Numune Training and Research Hospital, Trabzon, Turkey

${ }^{5}$ Department of Pathology, Region Training and Research Hospital, Erzurum, Turkey

${ }^{6}$ Department of Radiology, Hınıs State Hospital, Erzurum, Turkey

${ }^{7}$ Department of Surgery, Araklı State Hospital, Trabzon, Turkey

\begin{abstract}
Hydatid cyst is a parasitic disease that has been recognized endemically in many countries. Although the liver and lung are the most common organs involved by the disease, it may appear rarely in other tissues as a primary disease. In the ultrasonography of the neck taken from a 17 year old case who attended with a complaint of swelling in the neck, a partly regular, bounded cystic lesion of 33x28 mm in size was reported. When the cyst was thought to be hydatid during surgical exploration, this diagnosis was confirmed by histopathological verification of the specimen obtained. Whole abdomen ultrasonography and PA Chest Radiography were taken in order to determine whether there was another focus during the postoperative period. The Echinococcus ELISA test was performed as an immunological parameter. Treatment with Albendazole began after diagnosis during the postoperative period. Although hydatid cyst most commonly involves the liver and lung, it may be detected in all body tissues. Therefore hydatid cyst must be considered in the differential diagnosis in cystic lesions that are rarely encountered in body localizations in human, living in endemic regions. (Turkiye Parazitol Derg 2011; 35: 217-9)
\end{abstract}

Key Words: Hydatid cyst, E. granulosis, rare localization, neck

Received: 24.05.2011

Accepted: 22.08.2011

\section{ÖZET}

Hidatik kist birçok ülkede endemik olarak görülen paraziter bir hastalıktır. Hastalık en sık karaciğer ve akciğere yerleşmesine rağmen nadiren diğer dokularda da primer olarak karşımıza çıkmaktadır. Onyedi yaşında boyunda şişlik şikayeti ile başvuran olgunun yapılan boyun ulrasonografisinde $33 \times 28$ mm boyutlarında kısmen düzgün sınırlı kistik lezyon rapor edildi. Hastaya yapılan cerrahi müdahalede hidatik kist düşünülmesi üzerine elde edilen örneğin histopatolojik tanımlaması ile bu tanı doğrulandı. Postoperatif dönemde başka bir odak varlığı olup olmadığını ortaya koymak için tüm abdominal ultrasonografi ve PA Akciğer Grafisi çekildi. İmmunolojik parametre olarak Echinococcus ELISA testi yapıldı. Postoperatif dönemde tanı konulduktan sonra Albendazole tedavisi başlandı. Hidatik kist sıklıkla karaciğer ve akciğerde görülmesine rağmen tüm vücut dokularında tespit edilebilmektedir. Bu nedenle özellikle endemik bölgelerde yaşayanlarda nadir görülen vücut lokalizasyonlarındaki kistik lezyonlarda hidatik kist ayırıcı tanıda mutlaka düşünülmelidir. (Turkiye Parazitol Derg 2011; 35: 217-9)

Anahtar Sözcükler: Hidatik kist, E. granulasus, nadir lokalizasyon, boyun

Geliş Tarihi: 24.05.2011

Kabul Tarihi: 22.08.2011

Address for Correspondence / Yazışma Adresi: Dr. Uğur Kesici, Department of Surgery, Akçaabat Haçkalı Baba State Hospital, Trabzon, Turkey Phone: +90 5062398955 E-mail: ugurkesici77@mynet.com doi:10.5152/tpd.2011.55 


\section{INTRODUCTION}

Hydatid cyst disease is endemically seen in Africa, the Mediterranean coast of Europe, the Middle East, South America, Australia and Russia (1). It frequently locates in the liver, lungs, and rarely, in other body tissues (2). Liver hydatid cyst is a disease frequently seen in females (2).

Anamnesis, immunological tests, USG (Ultrasonography) and CT (Computer Tomography) are used in the diagnosis of hydatid cyst (3). Gharbi classification (4) and the classification produced by WHO (World Health Organization) in 2003 are used in USG (5). CT gives more detailed information about the localization and size of the cyst and its sensitivity is $100 \%$ (6). Medical, surgical treatment and PAIR (Puncture Aspiration Introduction of proscolocidal agent Reaspiration) are administered in accordance with the treatment stage and localization (3).

\section{CASE PRESENTATION}

In this case presentation, a 17 years old female case who applied to the Hınıs State Hospital, General Surgery Policlinic with the complaint of swelling in the neck, is discussed. The patient, who did not work at all, lived in a rural area. The general condition of the patient was good; she had no fever or weight loss. The patient had no known systemic disease. In the case history, it was reported that the swelling ofless than $0.5 \mathrm{~cm}$ that appeared 1 year earlier on the left side of the neck, had grown this year and caused pain. An approximately $3 \times 2 \mathrm{~cm}$ sized exophytic, cystic lesion was determined in the left sternocleidomastoid muscle superior-posterior in the physical examination of the case. Her systemic examination findings were otherwise normal. A partly regular, bounded cystic lesion of $33 \times 28 \mathrm{~mm}$ in size was determined in USG.

Surgical exploration was planned after the patient was informed about these findings; and the consent of patient was obtained. Whole Blood Count [ WBC (White Blood Cell): 9.4/ $\mathrm{mm}^{3}$ (3.5-10), HGB (Hemoglobin): 9.8g/dl (11.0-16.5), HCT (Hematocrit): $32.6 \%$ (35.0-50.0), PLT (Platelet): $325 / \mathrm{mm}^{3}$ (150-390)], coagulation tests [aPTT (activated Partial Thromboplastin Time): 28.4 sn (23-44 sn), PTZ (Prothrombin Time): 13.1 sn (11-17) INR (International Normalised Ratio): 0.910 (0.80-1.45)] and pregnancy test [ $\beta \mathrm{HCG}$ (Human Chorionic Gonadotropin): $0.5 \mathrm{mlU} / \mathrm{ml}$ (0.6-6.46)] were performed in the preoperative period. Excision was carried out under local anesthesia (40 mg Prilokain HCL. Citanest \%2 $20 \mathrm{ml}$ Vial. AstraZeneca. Turkey) under surgical conditions. We saw that clear fluid drained from the cyst cavity during exploration and laminar membrane from the cavity was excised.

The cyst was determined to be hydatid with the exploration findings of the case and with histopathological verification of the specimen obtained. Histopathological examination was performed by a senior pathologist. The thin cyst wall was monitored in lamellar structure where daughter vesicles were found in the lumen during examinations performed in stained preparations with 10X and 40X objective microscope (Olympus CX31) histopathologically. Positive stain was monitored with PAS (Periodic Acid Schiff's) stain performed histochemically and hydatid cyst was diagnosed. Histopathological findings are shown in Figure 1 and Figure 2.

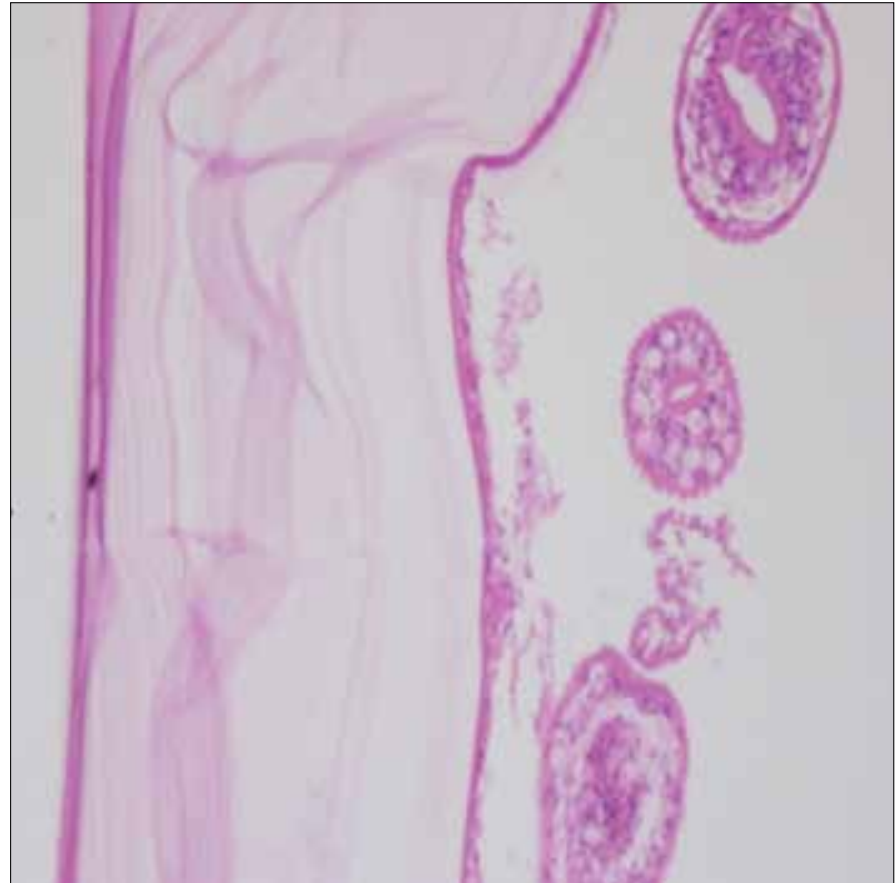

Figure 1. Histopathological findings ( $H \& E$ 40x)

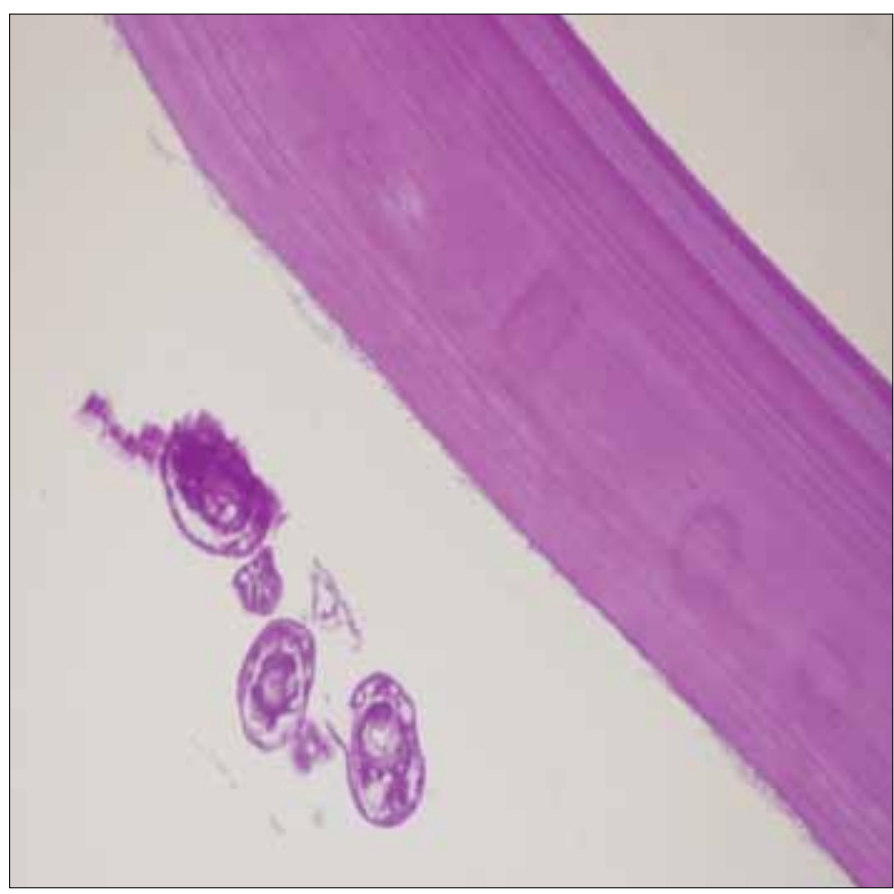

Figure 2. Histopathological findings (PAS 40x)

Whole Abdomen USG (Mindray/ DC-3 Model. 2010), PA Chest Radiography (US-X-Ray. 2001) and Echinococus IHA test were performed to find whether there was another focus. No other focus was found in Abdominal USG and PA (Posteroanterior) Chest Radiography. Echinococus ELISA (Enzyme-Linked Immunosorbent Assay) value was determined as $1.96 \mathrm{lU} / \mathrm{mL}$ (Pozitive: $\geq 1$, negative: $<1$ ). Treatment with Albendazole (Andazol 400 mg. 60 Film Tablet. Biofarma. Istanbul. Turkey), in two divided doses of a total of $15 \mathrm{mg} / \mathrm{kg} /$ day was started in the postoperative period (after diagnosis was definite) (7). Whole Blood 
Count and transaminase values [AST: $31 \mathrm{mU} / \mathrm{mL}$ (0-31), ALT: 31 $\mathrm{mU} / \mathrm{mL}(0-34)]$ were measured before Albendazole treatment.

\section{CONCLUSION}

Hydatid cyst is a disease with endemic features in some countries and regions of the world (1). Echinococcosis is a parasitic disease that develops cysts in both humans and animals caused by. Echinococus type cestodes and it continues to be a significant health problem of our country (2). The disease is more frequently seen in areas where animal breeding conditions are poor and where there are stray dogs. Humans are infected with the parasite egg by contact with dogs or from contaminated food. The larvae of this parasite egg appear in the small intestine and penetrate the intestinal wall and thus enter the circulatory system (1). Although the liver and lung are the most common organs involved by the disease, there are studies demonstrating that rarely it migrates in other tissues (2).

Anamnesis, immunological tests, USG and CT are used in the diagnosis of hydatid cyst. Medical, surgical treatment and PAIR are administered according to treatment stage and localization (3).

Hydatid Cyst is seen considerably rarely in the region of the neck. Ozekinci et al. (2) stated that only one hydatid cyst case out of 234 cases was diagnosed as located in neck region in Diyarbakir between 2002 and 2007. Here we presented a rarely seen, hydatid cyst located in the neck. In line with information given in the literature, there are a number of thyroid gland located cases (8-10). Also, hydatid cyst cases located in localizations of the neck other than the thyroid gland are reported by Riquet et al. (11) in 1982 and Soylu et al. (12) in 1995 and Ahmad et al. (13) in 2010.

In the case presented, because hydatid cyst was not considered and not diagnosed in the differential diagnosis before surgical exploration since it was located in a rarely seen localization, preoperative 15 days Albendazole treatment (14) suggested for cyst hydatid was not administered. Consequently, scolosidal agent administration to intracavitary injection before surgery was administered in the cyst cavity after surgical excision. $10 \%$ povidoneiodine solution was administered for 15 minutes as the scolosidal agent within this context (15). We considered that the risk of local recurrence should be high because preoperative Albendazole treatment was not started and intracavitary scolosidal agent was administered after surgical excision. Treatment with Albendazole, in two divided doses of a total $15 \mathrm{mg} / \mathrm{kg} /$ day began in the postoperative period (after diagnosis was definite) (7).

In conclusion, hydatid cyst still continues to be a very important health problem. The experience gained from this case is that one must certainly remember hydatid cyst in the differential diagnosis in 'cystic lesions' which are determined in places other than the usual body cavities, especially in endemic regions and demonstrate a significant growth in a 1 year period. Thus we consider that a lower risk of recurrence incidence can be achieved with diagnosis before surgery, effective preoperative preparation and a safer treatment approach.

\section{Conflict of Interest}

No conflict of interest was declared by the authors.

\section{REFERENCES}

1. Acar A, Rodop O, Yenilmez E, Baylan $O$, Oncül O. Case report: primary localization of a hydatid cyst in the adductor brevis muscle. Turkiye Parazitol Derg 2009; 33: 174-6.

2. Ozekinci S, Bakir S, Mizrak B. Evaluation of Cystic Echinococcosis Cases Given a Histopathologic Diagnosis from 2002 to 2007 in Diyarbakir. Turkiye Parazitol Derg 2009; 33: 232-35.

3. Sayek I, Onat D. Diagnosis and treatment of uncomplicated hydatid cyst of the liver. World J Surg 2001; 25: 21-7. [CrossRef]

4. Gharbi HA, Hassine W, Brauner MW, Dupuch K. Ultrasound examination of hydatic liver. Radiology 1981; 139: 459-63.

5. WHO Informal Working Group. International classification of ultrasound images in cystic echinococcosis for application in clinical and field epidemiological settings. Acta Trop 2003; 85: 253-61. [CrossRef]

6. Pedrosa I, Saíz A, Arrazola J, Ferreirós J, Pedrosa CS. Hydatid disease: radiologic and pathologic features and complications. Radiographics 2000; 20: 795-817.

7. Kapan S, Turhan AN, Kalaycı MU, Alis H, Aygun E. Albendazole is not effective for primary treatment of hepatic hdatid cysts. J Gastrointest Surg 2008; 12: 867-71. [CrossRef]

8. Moghimi M, Kamrava SK, Asghari AM, Heshmatzade Behzadi A, Jalessi M, Naraghi MM, et al. Primary echinococcal cyst in the thyroid gland: a case report from Iran. J Infect Dev Ctries 2009; 3: 732-4.

9. Perez PJA, Felmer EO, Carrasco EC, Gabrielli NM, Torrijos CC, Bastias NJA. Thyroid hydatid cyst: report of one case. Rev Med Chil 2008; 136: 896-9.

10. Oudidi A, El Alami MN. Hydatic cyst of thyroid gland. Ann Chir 2006; 131: 375-8. [CrossRef]

11. Riquet M, Cohen- Solal G, Soulier A. Hydatid cyst of the neck. One case. Ann Otolaryngol Chir Cervicofac 1982; 99: 269-72.

12. Soylu L, Aydogan LB, Kiroglu M, Kiroglu F, Javadzadeh A, Tuncer I, et al. Hydatic cyst in the head and neck area. Am J Otolaryngol 1995; 16: 123-5. [CrossRef]

13. Ahmad S, Jalil S, Saleem Y, Suleman BA, Chughtai N. Hydatid cyst at unusual sites: report of two cases in the neck and breast. J Pak Med Assoc 2010; 60: 232-4

14. Batrugno I, Gruttadauria S, Li Petri S, Cintorino D, Spada M, Di Francesco F, et al. Complex hydatid cyst of the liver: a single center's evolving approach to surgical treatment. Am Surg 2010; 76: 1011-5.

15. Ciftci IH, Esme H, Sahin DA, Solak O, Sezer M, Dilek ON. Effect of octonidine dihydrocholoride on viability of protoscoleses in hepatic and pulmonary hydatid diseases. J Natl Med Assoc 2007; 99: 674-7. 